\title{
Barcelona, Chicago, Toronto: Pre-Service Students Collaborate Using ICT to Learn about Teaching, Culture, and Themselves as Risk Takers
}

\author{
Isabel Alvarez (Corresponding author) \\ Dept. of Systematic and Social Pedagogy, Autonomous University of Barcelona \\ Building G6, 08193 Bellaterra (Cerdanyola del Vallès), Barcelona, Spain \\ Tel: 1-34-93-581-1411Ｅ-mail: Isabel.alvarez@uab.cat
}

\begin{abstract}
Brent Kilbourn
The Ontario Institute for Studies in Education, University of Toronto 252 Bloor St W, Toronto, ON M5S 1V6, Canada

Tel: 1-416-535-0738Ｅ-mail: brentkilbourn@gmail.com
\end{abstract}

George Olson

Roosevelt University

430 S Michigan Ave, Chicago, IL 60605, United States

Tel: 1-708-383-3744 E-mail: golson@ roosevelt.edu

Received: December 14, 2015 Accepted: December 29, 2015 Published: January 15, 2015 doi:10.5296/gjes.v2i1.8718

URL: http://dx.doi.org/10.5296/gjes.v2i1.8718

\begin{abstract}
This project used an ICT workspace to enable pre-service teachers in Barcelona, Spain, to communicate with in-service teachers in Chicago, USA, about issues of teaching and culture. This qualitative paper reports on the nature of the experience from the views of the participants and professors. Surmounting language differences, participants learned about another culture, learned about alternative ways of teaching, and learned about themselves as risk takers. The collaborative learning environment helped them transcend their immediate context.
\end{abstract}

Keywords: Collaborative learning, Comparative education, Constructivism, Educational 
technology, E-learning, Qualitative research, Teacher education 


\section{Introduction}

This paper reports on a project that addressed a common problem in pre-service educational technology: how can we effectively help pre-service teachers learn about and use ICT in responsible and innovative ways when they have their own classrooms? Pre-service teachers are commonly involved in mini-projects that ask them to imagine what it will be like when they have their own classroom. Useful as these experiences can be, many suffer from "un-realness" and perfunctory exercises (Lai, 2008; Compton et al., 2010; Cochran-Smith, 2011; Russell, 2012). The Barchito Project (Bar-Chi-To was the name given to the project because of the cities involved: Barcelona, Chicago, and Toronto) has been an effort to address the problem in a unique way by creating a collaborative learning experience with students from two different cultures and languages. Seven pre-service students from Barcelona, four in-service students from Chicago (and three professors from Barcelona, Chicago, and Toronto) were simultaneously enrolled in an education ICT course at their respective universities. As part of each course, participants used a Web-based program (Bereiter \& Scardamalia, 2010) to communicate with their peers (whom they had never met) $1 / 3$ the way around the world about becoming a teacher, views of teaching and learning, the role of ICT in the classroom, and culture in general.

The immediate aim of Barchito was to create an experience that could serve as a model for pre-service teachers in their future classrooms. Zhao (2007) has argued that "teachers need to receive intensive training that focuses on demonstration of technology integration strategies and application of those strategies in the curriculum." Similarly, pre-service teachers need exposure to rich experiences of using ICT to provide "images of possibility" for their future. We reasoned that if we could create a sufficiently positive learning experience, it would increase the likelihood that pre-service teachers would eventually use ICT in authentic and creative ways, including ICT as a vehicle for cultural understanding and tolerance. The research reported in this paper qualitatively analyzed the nature of participants' experience with international ICT based on their participation and reflective comments. During the course of Barchito we monitored how qualitatively effective such an approach was from the participants' and instructors' reflections.

\section{Approach to Teaching}

The theoretical framework underpinning the teaching in Barchito was constructivism (Dewey, 1938; Vygostsky, 1962) and incorporated these six qualities:

- using an ICT learning platform (Knowledge Forum) based on constructivist principles (Veermans \& Cesareni, 2005; Kollias et al., 2005; Bereiter \& Scardamalia, 2010; So et al., 2010; Barthel et al., 2013);

- providing a contextualized experience (Chan \& Chan, 2011) by accommodating learners' frames of reference in real world projects as part of their curriculum (Young, 2009);

- mediating the process with flexible guidelines and providing a low threshold for participation (while allowing a high ceiling) through the nature of the topics considered (Zhon-Zheng et al., 2013); 
- collaboratively designing topics for discussion (Golding, 2011);

- accommodating evolving issues-each week's activity was based on previous developments;

- supporting English learners efforts to communicate with native English speakers (Zhan, 2013).

\section{Research Method}

In qualitative research terms (Glesne \& Peshkin, 1992) Barchito is best regarded as a qualitative case study (Stake, 1995) of global ICT teaching and learning that spanned two months.

\subsection{Participants}

The seven Barcelona participants were in a pre-service, four-year, B.Ed. program for primary school in which students move through as a cohort, frequently taking courses together during the day. They were young and professionally inexperienced. Their first language was Catalan, second Spanish. Their English proficiency was weak. Few had any technology experience beyond word processing and none had international ICT experience. They were selected on the basis of their interest in communicating with their distant counterparts using ICT. Barchito was presented as an option in which sustained participation was a requirement for course credit.

The four Chicago participants were teachers enrolled in a part-time M.Ed. Program. They were working full-time and had contact with each other only during evening classes. They spoke neither Spanish nor Catalan. Their lives and professional experiences were more varied and more demanding than the Barcelona students, as expected from an older group. Barchito was an option for extra credit.

We are professors of education interested in the use of ICT in the classroom. Julia teaches in the B.Ed. program at the Autonomous University of Barcelona and was a participant with her Barcelona students. Sam taught in the graduate program at Chicago's Roosevelt University and was a participant with his Chicago students. Peter taught in the graduate program at the University of Toronto and was a participant/coordinator for Barchito. We met at an AERA conference in Montreal where we discussed the possibility of international, cross-cultural learning about ICT while using ICT as the vehicle for communication. We talked about the type of ICT learning experiences that would be interesting and educational and would be powerful enough to overcome fears of technology and language. We suspected that our cultural contexts were different enough to stimulate the sort of ICT learning and use that we envisioned.

\subsection{Data Sources}

\subsubsection{Knowledge Forum (KF) Entries}

$\mathrm{KF}$ is an ICT platform and was the primary source of data with 475 different entries spanning two months. KF preserves strings of entries (ideas and comments) in sequence which enables 
participants to translate and digest information and allows ongoing qualitative analysis of the process. The participants were asked to respond to the following weekly topics and share their ideas and reflections with each other and with professors: (1) My City-concerning where we lived, (2) Places I Like-local haunts, (3) Who am I-introductions, (4) Using KF - concerning technology, (5) Interesting Things - any topic, (6) Teaching, (7) Help Us-bringing to closure, (8) Videoconferences-goodbyes.

\subsubsection{Reflective Reports}

Students wrote 3 page reports (mid-way, end) in which they discussed pluses/minuses of Barchito.

\subsubsection{Feedback}

Both groups held feedback sessions (transcribed and augmented with professors' notes) at the end of Barchito in which issues about the project were addressed.

\subsubsection{Videoconferences}

Professors and students met synchronously.

\subsection{Approach to Analysis}

The primary data for Barchito came from KF. In standard qualitative practice, categories emerged during the course of the process. They were coded and grouped according to identified themes (Saldaña, 2013). Analysis of the students' reflective reports, feedback sessions, and videoconferences served to refine themes and were a way of triangulating our developing interpretations of the process.

\section{Results}

Numerous findings emerged from Barchito, but five themes stand out: Teaching, language, risk-taking, media, and nature of entries.

\subsection{Teaching/Learning Atmosphere}

One of the more significant outcomes of Barchito concerned the teaching/learning atmosphere that was created, largely due to the constructivist orientation to teaching. One aspect of that culture was the fact that participants were actually doing educational technology rather than just reading or talking about it. Although Barchito had a virtual aspect to it (that is, participants were not responsible for their own classroom), the fact that they were communicating with real strangers who could in some way be affected by them and, in turn, would affect them had an impact. Julia wrote:

"I guess, for my people, I could sense that this experience was reachable and real - they realized that things happen and we can make them happen and that by itself is an amazing thing, at least in our context. They could sense that you are serious with them, and that Barchito was not another project that they put away in a box. Part of what they've learned is a new method of working with people, a new way of teaching." 
The participatory mode of teaching/learning was particularly striking for the Barcelona participants because their customary mode was transmission; they recognized that they were breaking an educational tradition of reading and reporting on text.

Another aspect of the teaching/learning atmosphere concerned its informality and facilitative quality. We three professors were moderately personal and informal in KF entries. Our informality was unusual for the Barcelona participants who were surprised that professors would even participate in the conversation. They repeatedly expressed that we, as professors, took them seriously as individuals, engaged them, sought their opinions, and came across as human beings rather than stereotypical authority figures. They said, "we were being treated as grown-ups rather than children." When Julia asked what surprised them about the videoconferences, they said that it confirmed what they suspected from $\mathrm{KF}$-we professors were natural and good humoured, and that reduced their nervourness

"It was like it was between friends and everything would be okay, not strange. It was as though we were in a bar, side-by-side. Humour is very important. The topics are interesting and the informal language (like saying, "ha ha") makes it more familiar and not so strict. We want to highlight also that everything works and we are very motivated to do this new experience. At the beginning we had doubts about participating because we were afraid of the language." (feedback, Barcelona students).

They also pointed out that the physical distance between them and the professors in Chicago and Toronto made it easier to use informal language and helped create an informal atmosphere. They said that if conversations had been face-to-face it would have been very difficult for them to overcome the normal formality and distance between professors and students.

Participants from Barcelona repeatedly expressed how much they learned about a way of teaching that was different from the didactic modes they normally experienced. We conceptualize this as the difference between constructivist and transmission teaching, but there are also imbedded cultural issues in their comments, particularly with regard to conceptions of the role of authority in daily life. In the context of ICT, Kumar and Vigil (2011) have discussed the need for professors to create an atmosphere of respect and comfort. The Barcelona participants came to realize that professors are not always aloof and that learning can be enjoyable. It is easy to over generalize claims like this (not all Spanish professors are aloof, nor are all North American professors inviting), but there is a cultural context with respect to teaching/learning that marks a qualitative difference between North America and Europe. As a group they commented that it was the first time as students that they felt that they had been treated as though they were adults who had opinions worth listening to.

\subsection{Language}

Language emerged as a significant and complex issue, as we anticipated. The fact that Barchito was conducted primarily in English is the reason that the project was able to happen at all, since two of the professors and the Chicago participants spoke very little or no Spanish. 


\section{Ml Macrothink}

Global Journal of Educational Studies

ISSN 2377-3936

2016, Vol. 2, No. 1

Language was an ominous spectre for the Barcelona students, although the chance to learn more English was a huge motivator (Zhang, 2013), as was the novelty of talking with professors. In keeping with their comments about the teaching/learning atmosphere of Barchito, Barcelona participants commented that we professors were respectful toward people who did not speak English well and that helped them relax and take risks they might not have been comfortable in taking in other circumstances. They also said that a week between interchanges was needed so that they could comprehend and respond in English. On the fifth week (topic: "Teaching") we followed through on a participant's idea to have one week's discussion in Spanish with the help of Google translator. This proved extremely challenging for the Chicago participants and their entries in KF tapered off noticeably.

Table 1. Topics and number of entries

\begin{tabular}{|c|c|c|c|c|c|c|c|c|c|c|}
\hline \multirow[b]{2}{*}{ PARTICIPANTS } & \multicolumn{8}{|c|}{ Topics and Number of Entries* } & \multirow[b]{2}{*}{$\begin{array}{c}\text { Photo } \\
\text { sum }\end{array}$} & \multirow[b]{2}{*}{$\begin{array}{l}\text { Text } \\
\text { sum }\end{array}$} \\
\hline & $\begin{array}{c}\text { City } \\
\text { Week } 1\end{array}$ & $\begin{array}{c}\text { Place } \\
\text { Week } 2\end{array}$ & $\begin{array}{c}\text { Me } \\
\text { Week } 3\end{array}$ & $\begin{array}{c}\text { KF } \\
\text { Week } 4\end{array}$ & $\begin{array}{l}\text { Thing } \\
\text { Week } 5\end{array}$ & $\begin{array}{c}\text { Teach } \\
\text { Week } 6\end{array}$ & $\begin{array}{c}\text { Help } \\
\text { Week } 7\end{array}$ & $\begin{array}{c}\text { Video } \\
\text { Week } 8 \text { \& } 9\end{array}$ & & \\
\hline Nuria & 5 & 5 & 4 & 4 & 0 & 2 & 2 & 7 & 4 & 29 \\
\hline Peter & 15 & 9 & 6 & 7 & 14 & 5 & 8 & 10 & 14 & 74 \\
\hline Steve & 2 & 1 & $\mathbf{0}$ & 2 & 1 & $\mathbf{0}$ & 1 & 2 & $\mathbf{0}$ & 9 \\
\hline Sam & 18 & 9 & 4 & 7 & 6 & 6 & 4 & 3 & 2 & 57 \\
\hline Julia & 6 & 7 & 11 & 9 & 13 & 14 & 1 & 9 & 12 & 70 \\
\hline Joana & 5 & 2 & 3 & 2 & 2 & 2 & 2 & 5 & 6 & 23 \\
\hline Laura & 4 & 5 & 5 & 3 & 3 & 3 & 1 & 3 & 8 & 27 \\
\hline Sarah & 3 & 2 & 3 & 1 & 0 & 1 & 1 & 2 & 2 & 13 \\
\hline Bob & 5 & 3 & 2 & 2 & 0 & 1 & 0 & $\mathbf{0}$ & 1 & 13 \\
\hline Justina & 11 & 12 & 5 & 5 & 3 & 6 & 1 & 10 & 4 & 53 \\
\hline Aina & 3 & $\mathbf{0}$ & 1 & 1 & 3 & 3 & 3 & 5 & $\mathbf{0}$ & 19 \\
\hline Montse & 7 & 7 & 5 & 5 & 2 & 5 & 1 & 4 & 6 & 36 \\
\hline Emma & $\mathbf{0}$ & 3 & 7 & 0 & 5 & 1 & 0 & $\mathbf{0}$ & 0 & 16 \\
\hline Francesca & 5 & 1 & 5 & 1 & 7 & 4 & 2 & 11 & 28 & 36 \\
\hline TOTAL & 89 & 66 & 61 & 49 & 59 & 53 & 27 & 71 & 87 & 475 \\
\hline
\end{tabular}

Barchito Participation.

\subsection{Risk-Taking}

The Barcelona participants surprised themselves by taking risks they would not have imagined under other circumstances. First, they never had used an ICT workspace like KF, nor had they ever participated in an international experience with people they had never met. Second, although they had taken English in high school, they were seldom, if ever, actually called upon to read, write, or speak English and, consequently, they were uncertain about their ability to participate. Third, almost all of their education, including undergraduate 
school and teacher education, was in a didactic, transmission mode, in which the learning culture was one of "rendering 'right answers' rather than thinking well" (Windschitl, 2002, p. 51). Consequently, a mode of teaching/learning in which they were asked about their opinions and views put them on very unfamiliar ground. Fourth, the relationship between students and professors in Barcelona would be described as formal and distant. It would be uncommon for one of the Barcelona students to have an informal conversation with one of their professors. Consequently, the informality of Barchito and the way the three of us engaged them was yet another somewhat risky experience for them. Taken together, these four aspects echo Dewey (1933) decades ago when he argued that being a reflective teacher required wholehearted engagement and the willingness to take risks.

\subsection{Media}

The photos posted in Barchito were one of the more instrumental aspects of the experience, according to participants. The photos highlighted various aspects of another culture and served as an anchor for discussion, particularly for those who were struggling with language. A photo of a rather ordinary North American kitchen fascinated the participants (including their families) - their reaction was that the photo had revealed something private and indicated the risks that a professor would take. This led to a brief discussion in which it was clear that there were different conceptions of private spaces (Spanish normally would not regard a kitchen as a place for others to see). Photos like that of a kitchen were also the reason the project became a family experience, particularly for the Barcelona participants. They showed photos from the Chicago students and the American and Canadian professors to their parents, siblings, aunts, uncles, and boy/girl friends. During the feedback session, it was clear that the photos contributed to the relaxed, informal atmosphere that allowed participants to feel comfortable during the project (Kumar \& Vigil, 2011).

\subsection{Nature of Entries}

This theme emerged more from professors' emails to one another than from the students. One of the aims of Barchito was that participants would begin to talk with one another about teaching, becoming a teacher (Ertmer \& Ottenbreit-Leftwich, 2010), and the potential of the ICT they were experiencing, as well as issues that might be broadly regarded as "cultural". Given that the Chicago and Barcelona participants were strangers, in order to foster those kinds of discussions we needed to create an atmosphere in which they would feel comfortable expressing their views, and that meant that the topics would be relatively non-controversial. However, there was a built-in tension between wanting heart-felt entries that were honest and salient and not wanting entries that might cause discord or tumble into gripe sessions. One can imagine all sorts of "cultural" topics that might elicit passionate comments that would be counterproductive because the distance and the duration of Barchito would leave little room for damage control. No extreme entries emerged, but when the topic of "Teaching" and the potential of ICT was posted, some of the comments drifted to complaints about participants' own program and professors. While the interchange was short-lived, it highlighted for us the skills that are needed to foster discussion that is productive rather than simply venting frustration. 


\section{Discussion}

In our judgment, the experience of Barchito for the Barcelona participants was positive in a way we had hoped. Evidence from comments made in KF, reports, and feedback sessions suggested that their experience was memorable and had the sort of impact that could increase the likelihood of taking an ICT risk in the future. (Naturally, only a follow-up study would be able to address what sort of lasting effect our Project might have.) One participant said "this experience helped me to grow". Conquering her fears about language was part of it, but the challenge of participation made her "not feel brain dead", a sentiment echoed by others in the feedback session. Interestingly, and surprisingly, one participant commented in the feedback session that talking with the Chicago group changed her negative stereotype of Americans (and others around the table nodded their heads). They took pains to point out that their participation was genuine and, in spite of the initial requirement that they participate twice a week, they did not count the number of times they participated. They did it because they wanted to and, as one said, they regarded Barchito as a "life-experience rather than a course". One half year later, several participants approached Julia with an unsolicited proposal to develop and take a new course based on Barchito as part of their program requirement for their final year. One full year later, they were enrolled in a comparative education course and were developing a class project comparing teaching approaches between USA and Spain, which would have been unlikely had they not participated in Barchito. We take such things as encouraging signs about Barchito's potential.

The Chicago participants "loved the experience" and they were clearly excited with the interchange with Barcelona, but they were employed full-time and going to night-school already put a heavy burden on their busy lives. The fact that Barchito was an "add-on" to their packed schedules, coupled with their inability to hook-up easily outside of the evening class, meant that they were able to participate less frequently and with less intensity. Family and work made them isolated from one another - they did not form a support group, as did the cohort from Barcelona. In addition, there was no initial compulsory push (e.g., obligatory course credit) that helped move them into the habit of participation. However, there were indications that the project had some influence on their outlook and on how they worked on other projects in their program. For instance, Sam commented that two of his Chicago participants had worked together on another class project in which the approach they had taken seemed to be heavily influenced by their Barchito experience. Furthermore, the Chicago group talked about commonalities rather than differences. As one participant said,

"I guess my biggest thing that I learned was not finding differences but similarities. I took some time today and read through KF and, in a general sense, people are people wherever we go. I was reading my Barcelona colleagues' responses-their love of children in teaching and their dismay with bureaucracy."

\section{Conclusion}

This project was significant in our view because of its implications for learning ICT in pre-service programs and because of its implications for cultural understanding and tolerance. Projects like ours are not a panacea for timid ICT learners or for cultural discord, of course, 
and it is prudent to take a measured stance toward their potential for fostering cultural tolerance (Russell et al., 2013). Nevertheless, as educators, we found it immensely rewarding to see pre-service teachers fired-up about what they were learning as they communicated with peers and professors one third the way around the world, and it sets the mind to thinking about future possibilities. There was clear evidence that the "realness" of communicating with a stranger in a similar learning situation was compelling enough to allay fears about technology for most participants, and it was an experience that they will likely remember with some degree of vividness. More significantly, there was ample evidence that the participants were thirsty for knowledge about another "teaching" culture and that made them think about their own culture. The combination of immediacy, anticipation, discussion, and photographs was a potent vehicle for learning about cultural similarity/difference and for learning about themselves as learners and risk-takers. Berners-Lee, inventor of the World Wide Web, remarked that, among other things, technologies like the Internet and WWW can help build bridges between cultures (The Economist, 2007). He commented, "Clearly, any technology can be used for good or bad. That's always been the case, but in general, more communication is a good thing." We are excited about the potential of this sort of activity for learning about other cultures in a "safe" (Lafferty, 2015) way that, if done sensitively, could contribute to tolerant attitudes and fresh approaches to teaching and learning with ICT.

\section{Acknowledgements}

Barchito Data can be accessed from a link to the Autonomous University of Barcelona. The password can be obtained by emailing Dr. Isabel Alvarez, senior author of the paper. Pseudonyms were used to protect the identity of all participants. Any information that might reveal identity (e.g., specific location, dates, photos) was deleted or altered. There was no potential conflict of interest with the work reported in this paper.

\section{References}

Barthel, R., Ainsworth, S., \& Sharples, M. (2013). Collaborative knowledge building with shared video presentations. International Journal of Human-Computer Studies, 71(1), 59-75. http://dx.doi.org/10.1016/j.ijhcs.2012.02.006

Bereiter, C., \& Scardamalia, M. (2010). Can children really create knowledge? Canadian Journal of Learning and Technology, 36(1). Retrieved Dec 12, 2015 from http://cjlt.csj.ualberta.ca/index.php/cjlt/article/view/585

Chan, C., \& Chan, Y. (2011). Students' view of collaboration and online participation in knowledge forum. Computers and Education, 57, 1445-1457. http://dx.doi.org/10.1016/j.compedu.2010.09.003

Cochran-Smith, M. (2011). Does learning to teach ever end? Kappa Delta Pi Record, 48(1), 22-24. http://dx.doi.org/10.1080/00228958.2011.10516719

Compton, L., Davis, N., \& Correia, A. (2010). Pre-service teachers' preconceptions, misconceptions, and concerns about virtual schooling. Distance Education, 31(1), 37-54. http://dx.doi.org/10.1080/01587911003725006 


\section{MInstitute Macrothink $_{\text {Int }}$}

Global Journal of Educational Studies ISSN 2377-3936 2016, Vol. 2, No. 1

Dewey, J. (1933). How we think: a restatement of the relation of reflective thinking to the educative process. Chicago: Henry Regnery.

Dewey, J. (1938). Experience and education. New York: Macmillan.

Ertmer, P., \& Ottenbreit-Leftwich, A. T. (2010). Teacher technology change: how knowledge, confidence, beliefs, and culture intersect. Journal of Research on Technology in Education, 42(3), 255-284. Retrieved Dec 12, 2015 from http://files.eric.ed.gov/fulltext/EJ882506.pdf

Glesne, C., \& Peshkin, A. (1992). Becoming Qualitative Researchers: An introduction. New York: Longman.

Goldin, C. (2011). The many faces of constructivist discussion. Educational Philosophy and Theory, 43(5), 467-483. http://dx.doi.org/10.1111/j.1469-5812.2008.00481.x

Hudson, P. B. (2013). Desirable attributes and practices for mentees: Mentor teachers' expectations. European Journal of Educational Research, 2(3), 107-118. Retrieved Dec 12, 2015 from http://eurojedu.com/EU-JER_2_3_107_Hudson.pdf

Irwin, B., \& Boulton, H. (2010). Analysing the development of professional identity in blogging discourse. In C. Rust (Ed.), Improving student learning: For the twenty-first century learner (pp. 22-32). Proceedings of the 17th improving student learning symposium, Imperial College, London, 7-9 Sep. 2009.

Kollias, V., Mamalougos, N., Vamvakoussi, X., Lakkala, M., \& Vosniadou, St. (2005). Teachers' attitudes to and beliefs about web-based Collaborative Learning Environments in the context of an international implementation. Computers and Education, 45, 295-315. http://dx.doi.org/10.1016/j.compedu.2005.04.012

Kumar, S., \& Vigil, K. (2011). The net generation as preservice teachers: transferring familiarity with new technologies to educational environments. Journal of Digital Learning in Teacher Education, 27(4), 144-153. Retrieved Dec 12, 2015 from http://files.eric.ed.gov/fulltext/EJ936543.pdf

Lafferty, K. (2015). Practices of cooperating teachers contributing to a high quality field experience. Association of Teacher Educators Annual Meeting. Retrieved Dec 12, 2015 from http://www.academia.edu/11182460/Practices_of_Cooperating_Teachers_Contributing_to_a_ High_Quality_Field_Experience

Lai, K. (2008). ICT supporting the learning process: the premise, reality, and promise. In J. Voogt, \& Knezek (Eds.), International handbook of information technology in primary and secondary education (pp. 215-230). New York: Springer. http://dx.doi.org/10.1007/978-0-387-73315-9_13

Russell, J. (2012). Knowledge building: what is it all about? Computers in New Zealand Schools, 24(3). $\quad$ Retrieved Dec 12, 2015 from http://education2x.otago.ac.nz/cinzs/mod/resource/view.php?id=389

Russell, L. R., Kinuthia, W. L., Lokey-Vega, A., Tsang-Kosma, W., \& Madathany, R. (2013). 
Identifying complex cultural interactions in the instructional design process: A case study of a cross-border, cross-sector training for innovation program. Education Technology Research Development, 61, 707-732. Retrieved Dec 12, 2015 from http://scholarworks.gsu.edu/cgi/viewcontent.cgi?article=1081\&context=msit_diss

Saldaña, J. (2013). The coding manual for qualitative researchers (2nd ed.). Thousand Oaks, CA: Sage Publications.

So, H. et al. (2010). Designing collaborative knowledge building environments accessible to all learners: Impacts and design challenges, Computers and Education, 54, 479-490. http://dx.doi.org/10.1016/j.compedu.2009.08.031

Stake, R. (1995). The art of case study research. Thousand Oaks, CA: Sage Publications.

Straub, E. (2009). Understanding Technology Adoption: Theory and Future Directions for Informal Learning. Review of Educational Research, 79(2), 625-649. http://dx.doi.org/10.3102/0034654308325896

The Economist Technology Quarterly. (2007). Watching the web grow up. The Economist, March 10 ${ }^{\text {th }}$ pp. 29-30. Retrieved Dec 12, 2015 from http://www.economist.com/node/8766093

Veermans, M., \& Cesareni, C. (2005). The nature of the discourse in web-based collaborative learning environments: Case studies from four different countries. Computers and Education, 45(3), 316-336. $\quad$ Retrieved Dec 12, 2015 from https://www.tlu.ee/ kpata/haridustehnoloogiaTLU/discoursecontentcomparison.pdf

Vygostsky, L. (1962). Thought and language. Cambridge, MA: MIT Press.

Windschitl, M. (2002). Framing constructivism in practice as the negotiation of dilemmas: an analysis of the conceptual, pedagogical, cultural, and political challenges facing teachers. Review of Educational Research, 72(2), 131-175. http://dx.doi.org/10.3102/00346543072002131

Young, P. A. (2009). Instructional design frameworks and intercultural models. Hershey, PA: IGI Global/Information Science Publishing.

Zhang, H. (2013). Pedagogical challenges of spoken English learning in the Second Life virtual world: A case study. British Journal of Educational Technology, 44(2), 243-254. http://dx.doi.org/ 10.1111/j.1467-8535.2012.01312.x

Zhao, Y. (2007). Social studies teachers' perspectives of technology integration. Journal of Technology and Teacher Education, 15(3), 311-333. Retrieved Dec 12, 2015 from https://getd.libs.uga.edu/pdfs/zhao_yali_200405_phd.pdf

Zhon-Zheng, L., Yuan-Band, C., \& Chen-Chung, L. (2013). A constructionism framework for designing game-like learning systems: Its effect on different learners. British Journal of Educational Technology, 44(2), 208-224. http://dx.doi.org/10.1111/j.1467-8535.2012.01305.x 


\section{Copyright Disclaimer}

Copyright for this article is retained by the author(s), with first publication rights granted to the journal.

This is an open-access article distributed under the terms and conditions of the Creative Commons Attribution license (http://creativecommons.org/licenses/by/3.0/). 